\title{
Ăg Elemanı Özelliklerinin Sayısal Model Sonuçları Üzerine Etkisinin Belirlenmesi
}

\author{
Oğuz ŞiMŞEK ${ }^{* 1}$, Hüseyin IŞSEK ${ }^{1}$, M. Sami AKÖZ² \\ ${ }^{1}$ Harran Üniversitesi, Mühendislik Fakültesi, İnşaat Mühendisliği Bölümü, Şanlıurfa \\ ${ }^{2}$ Çukurova Üniversitesi, Mühendislik Fakültesi, İnşaat Mühendisliği Bölümü, Adana
}

Geliş tarihi: 24.03.2020 Kabul tarihi: 15.05.2020

\section{$\ddot{O} z$}

Gelişen teknolojiyle birlikte bilgisayar yazılımları, karmaşık mühendislik problemlerin çözümünde oldukça sık kullanılmaya başlanmıştır. Kullanılan bu yazılımlardan elde edilen sonuçların doğruluğunun test edilmesi için fiziksel model deneyleri yapılmakta ve elde edilen sonuçlar, sayısal model sonuçları ile karşılaştırılmaktadır. Sayısal model sonuçları üzerinde, ağ yapısı özellikleri, kullanılan türbülans modeli, iterasyon sayısı ve adımı büyüklüğü gibi parametrelerin etkili olduğu bilinmektedir. Bu çalışmada, eğrisel geniş başlıklı savak üzerinden geçen akımın sayısal modellemesinde farklı geometrik özelliklere sahip çözüm ağları tasarlanmıştır. Akımı idare eden temel denklemlerin çözümü, sonlu hacimler yöntemine dayalı ANSYS-Fluent yazılımıyla gerçekleştirilmiştir. Sayısal hesaplamalarda, Reynolds Ortalamalı

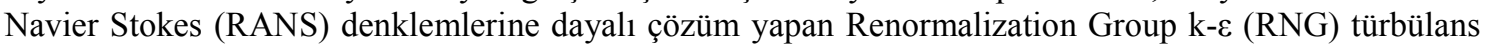
modeli ve su-hava arakesitinin belirlenmesinde ise Akışkan Hacimleri Yöntemi kullanılmıştır. Sayısal olarak elde edilen su yüzü ve hız profilleri, deneysel sonuçlar ile karşılaştırılarak optimum çözüm ağının tipi ve boyutu belirlenmiştir. Ayrıca, hız profilleri üzerinde duvar yakını fonksiyonlarının etkileri araştırılmıştır. Deneysel ve farklı ağ yapıları kullanılarak elde edilen sayısal hız profillerinin karşılaştırılmasından, çok küçük elemanlardan oluşan hesaplama ağı yapısının sayısal model sonuçları üzerinde önemli ölçüde iyileştirme yapmadığı belirlenmiştir.

Anahtar Kelimeler: Akışkan hacimleri yöntemi, Ăg eleman boyutu, Duvar yakını fonksiyonu, Sayısal modelleme

\section{Determining the Effect of Computational Grid Properties on Numerical Model Results}

\begin{abstract}
With the developing technology, computer software has started to be used frequently in solving complex engineering problems. Physical model experiments are carried out to test the accuracy of these software
\end{abstract}

\footnotetext{
*Sorumlu yazar (Corresponding author): Oğuz ŞİMŞEK, oguzsimsek@harran.edu.tr
} 
and the results are compared with the numerical model results. It is known that the properties of the grid structure, the turbulence model, the number of iterations and the step size have effects on the numerical model results. In the numerical modeling of the flow passing over the curvilinear broad-crested weir, solution grids with different geometrical features are designed. The basic equations are solved by ANSYS-Fluent package program based on finite volume method. In numerical calculations, the Renormalization Group k- $\varepsilon$ (RNG) turbulence model based on Reynolds Average Navier Stokes (RANS) equations and Volumes of Fluid (VOF) Method was used to determine the water-air intersection. The optimum solution grid type and size were determined by comparing the obtained numerical model results with the experimental results. In addition, numerical modeling has been done with different near wall treatment functions. It has been determined from the comparison of numerical velocity profiles obtained by using experimental and different grid structures, creating a very tight grid structure did not significantly improve the numerical model results.

Keywords: Volume of fluid (VOF), Grid size, Near wall function, Numerical model

\section{GİRIŞ}

Savaklar, açık kanallarda ve akarsularda akımı düzenlemek ve debiyi ölçmek üzere yaygın olarak kullanılan hidrolik yapılardır. Savaklar, akarsu veya açık kanal en kesitini tamamen kapatmakta ve akıma dik doğrultuda inşa edilmektedir. Savağın akım alanına inşa edilmesiyle birlikte, akım rejiminde değişiklik meydana gelmekte, savak membasında kritik alt1-nehir rejimi $(\mathrm{Fr}<1)$, savak kretinde kritik ( $\mathrm{Fr}=1)$, savak mansabında ise kritik üstü-sel rejimi $(\mathrm{Fr}>1)$ akım koşulları oluşmaktadır.

Savaklar trapez, dikdörtgen, üçgen ve eğrisel geniş başlıklı olmak üzere farklı tiplerde inşa edilebilmektedir. Savak geometrisinin akım çizgilerine uyarlanmasıyla, akımda meydana gelen enerji kayıpları azalmaktadır. Araştırmalar, farklı geometrik özelliklere sahip savakların hidrolik ve geometrik özelliklerinin belirlenmesine yönelik olarak devam etmektedir. Hidrolik açıdan daha elverişli savak geometrilerinin belirlenmesi için fiziksel model deneyleri laboratuvar ortamında yapılabilmektedir. $\mathrm{Bu}$ deneylerde, ölçek etkilerinden kaynaklanan hataların yanında, ölçümü yapan kişilerin ölçüm hassasiyetinden kaynaklanan hatalar da söz konusu olmaktadır. Bunun yanında, bilgisayar teknolojisinde meydana gelen gelişmeler, birçok mühendislik alanında karmaşık problemlerin çözümünü mümkün hale getirmiştir. $\mathrm{Bu}$ gelişen teknolojiyle birlikte, hidrolik mühendisliği açısından da su-yapı etkileşiminin bulunduğu karmaşı $1 \mathrm{k}$ akım problemlerinin çözümü, bilgisayar ortamında kolayca yapılmaktadır. Ayrıca, bilgisayar ortamında yapılan sayısal modellemeler, fiziksel modelin aksine, ek ölçüm cihazları kullanmadan akım ile ilgili istenilen birçok özelliği elde etme imkânı sunmaktadır. Bunun yanında, fiziksel model çalışmalarına kıyasla sayısal model deneyleri, zaman ve maddi açıdan daha ekonomik olmasının yanında insan gücü ihtiyacını azalmakta ve hata oranı fiziksel model deneylerine kıyasla küçük olmaktadır. Fakat, sayısal model sonuçlarının güvenirliliğinin test edilmesi için de fiziksel model çalışmaları ile doğrulanmasına ihtiyaç vardır. Çünkü, sayısal model sonuçları üzerinde, temel denklemlerin çözümü için kullanılan hesaplama yöntemi, hesaplama ağının tasarımı, seçilen türbülans modeli, duvar yakını modeli, iterasyon sayısı, iterasyon adımının büyüklüğü ve çözüm süresi gibi birçok parametre etkilidir. Farklı araştırmacılar tarafından, açık kanal akımları ve yapılarla etkileşim halinde bulunan akımların sayısal modellemesi yapılmıştır [1-5]. Farklı çalışmalarda, farklı savak modellerinin sayısal olarak modellenmesinde farklı türbülans modellerinin başarılı olduğu belirtilmiştir. Birçok araştırmacı, ağ yapısından bağımsız sayısal çözümler elde etmek amacıyla A $\breve{g}$ Yakınsama indeksi yöntemini ve su-hava arakesitinin belirlenmesi için ise akışkan hacimleri yöntemini kullanmıştır. A $\breve{g}$ yakınsama yöntemi, en 
az 3 farklı çözüm ağı tasarımını zorunlu kılmakta ve akışkan hacimleri yöntemi ise akım profilinin belirlenmesinde oldukça başarılı sonuçlar vermektedir [6-10]. Her ne kadar ağ yapısının sonuçlar üzerindeki etkisi ağ yakınsama indeksi yöntemi ile test ediliyor olsa da çok farklı yoğunluğa sahip olmayan hesaplama ağlarının ağ yakınsama indeksinde kriteri sağladığı görülmektedir. $\mathrm{Bu}$ yöntemde, başlangıç ağ yapısının belirlenmesi oldukça önem arz etmektedir. Son yıllarda fiziksel modellerin maliyetlerini azaltmak için yapılan sayısal modellemelerde özellikle bilgisayar gücünün kullanımını ve donanım ihtiyacını ciddi anlamda arttıran ă̆ yapısının en kadar küçük ağ elemanlarından oluşacağının belirlenmesi önemli bir konudur. Bu çalışmayla, hesaplama ağının herhangi bir indeks kullanmadan uygunluğunun belirlenmesi ve çok ince elemanlardan oluşan hesaplama ağlarının sayısal sonuçlar üzerindeki etkisi belirlenmeye çalışılmıştır.

$\mathrm{Bu}$ çalışmada, eğrisel geniş başlıklı savak ile etkileşim halindeki açık kanal akımının hız alanı ve su yüzü profili, sonlu hacimler yöntemine dayalı ANSYS-Fluent programı kullanılarak sayısal olarak elde edilmiştir. Akımın hareketini idare eden süreklilik ve momentum denklemleri, Renormalization Group (RNG) türbülans modeliyle, farklı geometrik özelliklere sahip çözüm ağları ve farklı duvar fonksiyonları kullanılarak çözülmüştür. Su-hava arakesitinin belirlenmesinde akışkan hacimleri yönteminden yararlanılmıştır. Farklı geometrik özelliklere sahip çözüm ağları ve duvar yakını modellemesi kullanılarak elde edilen sayısal hız ve su yüzü profilleri, Şimşek ve arkadaşları [11] tarafindan elde edilen deneysel sonuçlar ile karşılaştırılmıştır.

\section{MATERYAL VE METOT}

\subsection{Deneyler}

Deneyler, Şimşek ve arkadaşları [11] tarafından Şekil 1'de şematik olarak verilen açık kanal modelinde yapılmıştır. Açık kanal modelinin genişliği, yüksekliği ve uzunluğu sırasıyla $20 \mathrm{~cm}$,
$20 \mathrm{~cm}$ ve $240 \mathrm{~cm}$ 'dir. Açık kanalın yan duvarları ve tabanı cam malzemeden yapılmış ve kanalın tüm yüzeyleri hidrolik açıdan cilalıdır. Taban genişliği $70 \mathrm{~cm}$, kret yüksekliği $6,8 \mathrm{~cm}$ olan eğrisel geniş başlıklı savak, kanal başlangıcından $70 \mathrm{~cm}$ uzağa yerleştirilmiştir.

Deneylerde su yüzü profili limnimetreyle, $x$ doğrultusundaki hız bileşeni $(u)$ tek boyutlu Laser Doppler Anenometry (LDA) kullanılarak ölçülmüştür. Deneysel ölçümlerde akım debisi $\mathrm{Q}=0,00824 \mathrm{~m}^{3} / \mathrm{s}$, memba bölgesindeki su derinliği $\mathrm{h}_{\mathrm{o}}=0,146 \mathrm{~m}$, kesit ortalama h1z1 $\mathrm{V}_{\mathrm{o}}=0,288 \mathrm{~m} / \mathrm{s}$, Froude say1s1 $\mathrm{Fr}_{\mathrm{o}}=0,2407$ ve Reynolds say1s1 $\mathrm{Re}_{\mathrm{o}}=24.000$ 'dir [11]. Sayısal modellemeler, deneylerle aynı koşullara sahip açık kanal akımı için gerçekleştirilmiştir.

\subsection{Sayısal Modelleme}

\subsubsection{Temel Denklemler ve Türbülans Modeli}

Eğrisel geniş başlıklı savakla etkileşimde bulunan açık akımının hareketini idare eden temel denklemler kütlenin ve momentumun korunumu (Reynolds-ortalamalı Navier-Stokes) denklemleri, indis notasyonunda sırasıyla aşağıdaki gibidir (Eşitlik 1-2):

$\frac{\partial \overline{\mathrm{u}}_{\mathrm{i}}}{\partial \mathrm{x}_{\mathrm{i}}}=0$

$\rho\left(\frac{\partial \bar{u}_{i}}{\partial t}+\bar{u}_{j} \frac{\partial \bar{u}_{i}}{\partial x_{j}}\right)=\rho g_{i}-\frac{\partial \bar{p}}{\partial x_{i}}+\mu \frac{\partial^{2} \bar{u}_{i}}{\partial x_{j}^{2}}+\frac{\partial \tau_{i j}}{\partial x_{j}}$

Eşitlik 1 ve 2'de $u_{i}, x_{i}$ doğrultusundaki hız bileşeni, $g$ yer çekimi ivmesi, $p$ basınç, $\mu$ dinamik viskozite, $\rho$ akışkan yoğunluğu ve $\tau_{i j}$ türbülans (Reynolds) gerilmeleridir. Bu çalışmaya konu olan üç boyutlu akımı idare eden yukarıdaki 4 adet denklem 10 adet bilinmeyen içermektedir, bunlar: üç hız bileşeni $\bar{u}_{i}$, basınç $\bar{p}$ ve 6 bağımsız Reynolds gerilmesidir $\left(\rho \overline{u_{i}^{\prime} u_{j}^{\prime}}\right)$. Böylece, denklem takımının çözülebilmesi için türbülans gerilmelerinin tanımlanmasına ihtiyaç duyulmaktadır. İki boyutlu akımda ise bu bilinmeyen sayısı 6'ya düşmektedir. 


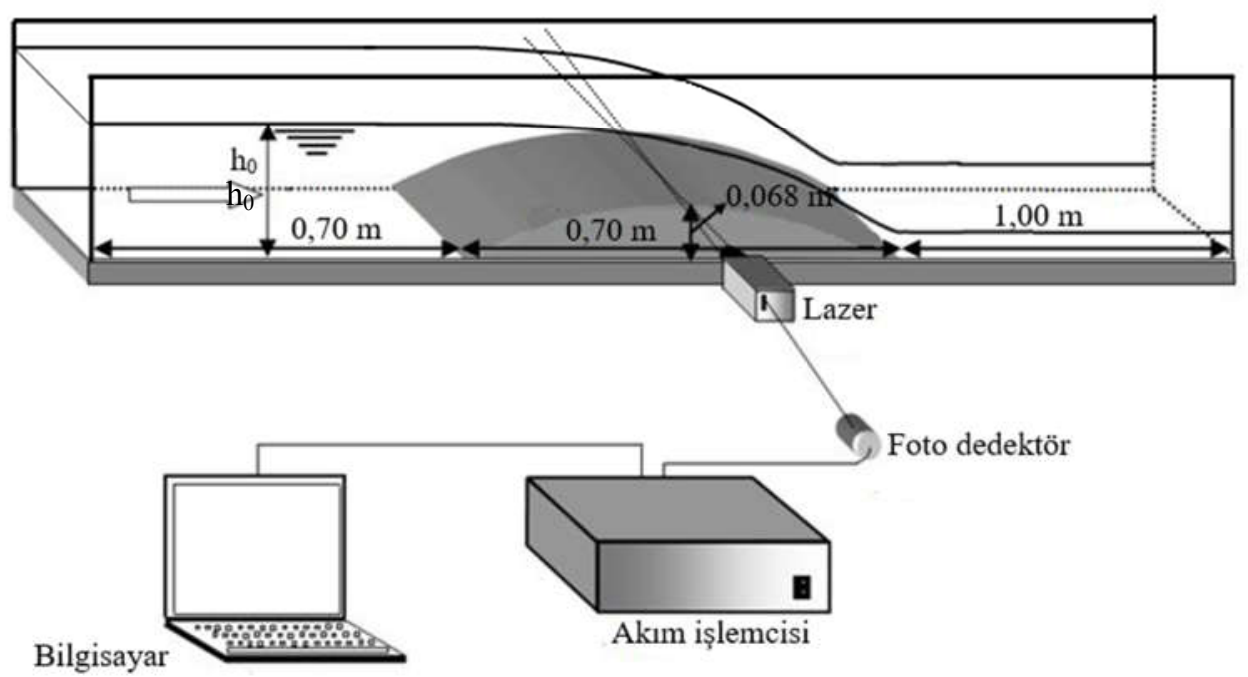

Şekil 1. Deney düzeneği ve LDA hız ölçüm sistemi [11]

$\mathrm{Bu}$ sorun, yukarıdaki zamansal-ortalama eşitliklerinin sayısal çözümü sürecinde, eşitliklerde yer alan türbülans gerilmelerinin uygun türbülans kapatma modelleriyle tanımlanmasını zorunlu kılmaktadır. Türbülans viskozitesinin doğrusal olarak ifade edilmesini esas alan Boussinesq yaklaşımına göre Eşitlik 2'deki türbülans kayma gerilmeleri bünye denklemi ile, sıkışmayan akımlar için aşağıdaki gibi verilmiştir (Eşitlik 3):

$\tau_{\mathrm{ij}}=-\rho \overline{u_{\mathrm{i}}^{\prime} \mathrm{u}_{\mathrm{j}}^{\prime}}=\mu_{\mathrm{t}}\left(\frac{\partial \overline{\mathrm{u}}_{\mathrm{i}}}{\partial \mathrm{x}_{\mathrm{j}}}+\frac{\partial \overline{\mathrm{u}}_{\mathrm{j}}}{\partial \mathrm{x}_{\mathrm{i}}}\right)-\frac{2}{3} \rho \mathrm{k} \delta_{\mathrm{ij}}$

burada $u_{i}^{\prime}$ ve $u_{j}^{\prime}$ yatay ve düşey türbülans hız sapınçları, $\mu_{t}$ türbülans viskozitesi, $k\left(=\overline{\mathrm{u}_{\mathrm{i}}^{\prime} \mathrm{u}_{\mathrm{i}}^{\prime}} / 2\right)$ türbülans kinetik enerjisi ve $\delta_{i j}$ Kronecker deltadır.

Şimşek ve arkadaşları [11] çalışmalarında, Eşitlik 3 'te görülen $\mu_{t}$ türbülans viskozitesinin hesaplanmasinda Reynolds Ortalamalı Navier Stokes denklemlerinin (RANS) çözümüne dayalı farklı türbülans modelleri kullanmış ve farklı türbülans modelleri kullanılarak elde edilen sayısal model sonuçları deneysel sonuçlarla karşılaştırmıştır. Ortalama Karesel Hata kriterine göre yapılan karşılaştırma sonucunda RNG [12] türbülans modelinin çalışmada kullanılan diğer türbülans modellerine kıyasla, hız alanını ve su yüzü profilini belirlemede daha başarılı olduğu belirtilmiştir. Bu çalışmada, eğrisel geniş başlıklı savak üzerinden geçen akımın sayısal modellenmesinde farklı türbülans modellerinin değerlendirilmesinden ziyade, sayisal model sonuçları üzerinde etkili olduğu bilinen hesaplama ağı tasarımı detaylı olarak irdelenmiştir.

\subsubsection{Akıșkan Hacimleri Yöntemi}

Sayısal modellemede su yüzü profillerinin belirlenmesi için Akışkan Hacimleri Yöntemi kullanılmıştır. $\mathrm{Bu}$ yöntem, sayısal modellemede kullanılan hesaplama ağının her bir hücresinin su ile tamamen dolu, kısmen su ile dolu veya tamamen boş (tamamen hava ile dolu) olduğunu belirlemektedir. Hacimsel doluluk oranını temsilen bir akışkan hacmi (F) tanımlanır. Eşitlik 4'te F'nin taşınım denklemi görülmektedir. $\mathrm{F}=1$ için ağ elemanı tamamen su ile dolu, $\mathrm{F}=0$ için tamamen boş (hava ile dolu) ve $0<\mathrm{F}<1$ için ağ elemanı kısmen dolu olarak tanımlanmaktadır. Serbest su yüzü profilinin Akışkan Hacimleri Yöntemi ile hesaplanmasında "Geo-Reconstruct" yaklaşımı kullanılmıştır [13,14] (Eşitlik 4).

$$
\frac{\partial \mathrm{F}}{\partial \mathrm{t}}+\mathrm{u} \frac{\partial \mathrm{F}}{\partial \mathrm{x}}+\mathrm{v} \frac{\partial \mathrm{F}}{\partial \mathrm{y}}+\mathrm{w} \frac{\partial \mathrm{F}}{\partial \mathrm{z}}=0
$$




\subsection{3. Çözüm Bölgesi, Sınır ve Başlangıc Sartları}

Şekil 2'de, eğrisel geniş başlıklı savak üzerinden geçen açık kanal akımının sayısal modellemesinde kullanılan çözüm bölgesi, başlangıç ve sınır şartları verilmiştir. $\mathrm{x}-\mathrm{y}$ koordinat takımının orjini olarak, çözüm bölgesinin sol alt köşesi belirlenmiş ve sonuçlar bu tanımlanan eksen takımına göre değerlendirilmiştir. Sayısal çözümde, çözüm bölgesinin çıkış ve üst sınırında sıfır basınç $(p=0)$, kanal tabanında ve eğrisel geniş başlıklı savak yüzeyinde sıfır hız sınır şartı, yani $u=v=0$ olarak tanımlanmıştır. Ayrıca, giriş sınırın hemen üstünde su bulunmayan kısımda da $p=0$ sinır şartı verilmiştir. Giriş sınırında ise deneysel verilerden elde edilen yatay doğrultudaki ortalama hız bileşeni $u=0,289 \mathrm{~m} / \mathrm{s}$ ve düșey hız bileșeni $v=0$, türbülans şiddeti $\% 5$ ve hidrolik yarıçap 0,059 olarak verilmiştir. Başlangıç şartı olarak ise sadece giriş sınırında suyun bu bölgeden girdiğini ifade etmek üzere $\mathrm{F}=1$ ve çözüm bölgesinin tamamı boş yani $\mathrm{F}=0$ olarak tanımlanmıştır.

Sayısal modellemede zamana bağlı çözüm gerçekleştirilmiş, giriş ve çıkış sınırındaki debi farkının toplam debinin \%1'inden küçük olduğu durumda sayısal çözüm tamamlanmıştır. Sayısal modellemelerde, courant sayısının $\left(\mathrm{C}_{\mathrm{n}}=\Delta \mathrm{t} /\left(\Delta \mathrm{x}_{\mathrm{ag}} / \mathrm{v}_{\mathrm{akım}}\right) \quad \Delta \mathrm{t} \quad\right.$ zaman $\quad$ adımı, $\Delta \mathrm{x}_{\mathrm{ag}}$ hesaplama ağının $\mathrm{x}$ doğrultusundaki boyutu, $\mathrm{V}_{\mathrm{akım}}$ akım hızı) değerinden küçük olması koşuluna bağlı iterasyon zaman adımı kullanılan program tarafindan otomatik olarak belirlenmiștir. Her bir iterasyon adımında yapılan iterasyon sayısı ise 10 olarak seçilmiştir. Ayrıca, süreklilik, $x$ ve $y$ doğrultusundaki hız bileșeni, kinetik enerji ve kinetik enerji özgül kayıp oranı denklemlerinin çözümünde yakınsama kriteri 0,0001 olarak alınmıştır. Akımı idare eden süreklilik ve momentum denklemlerinin çözümünde, sonlu hacimler yöntemine dayalı çözüm yapan ANSYS-Fluent ${ }^{\circledR} \quad$ v.12.1 paket programından yararlanılmıştır.

\subsubsection{Hesaplama Ăğ}

Sayısal model sonuçları üzerinde hesaplama ağ tasarımın oldukça etkili olduğu sayısal modelleme yapanlar tarafindan bilinmektedir. Sayısal çözümlerde kaba tasarlanmış (büyük ağ elemanlarından oluşan) hesaplama ağlarından dolayı ayrıklaştırma hata payı büyümekte ve sayısal sonuçların gerçekten uzaklaşmasına neden olmaktadır. Çok ince tasarlanmış (çok küçük ağ elemanlarından oluşan) hesaplama ağına sahip bir sayısal ağla problemin çözümü için ise yüksek kapasiteli bilgisayarlar gerekmekte ve çözümün tamamlanma süresi oldukça uzamaktadır. Bu nedenlerden dolayı, hesaplama ağının en optimum olarak tasarlanması sayısal modelleme sonuçları açısından önemlidir. Hesaplama ağı tasarımı, viskoz alt tabakanın belirlenmesinde ve özellikle sınır tabakasının gelişim gösterdiği katı sınıra yakın bölgedeki hız profillerinin belirlenmesinde oldukça etkin rol oynamaktadır. Özellikle zamana bağlı olarak değişkenlik gösteren hız alanlarının belirlenmesinde hesaplama ağı, sonuçları tamamen değiştirebilmektedir.

$\mathrm{Bu}$ çalışmada, farklı ağ eleman boyutlarında ve tiplerinde sayısal modellemeler gerçekleştirilerek, ağ yapısının sayısal model sonuçları üzerindeki etkisi araştırılmıştır. Öncelikle düzenli dikdörtgen elemanlardan oluşan farklı yoğunluktaki ağlar tasarlanmıştır. Farklı boyuttaki ağ elemanlardan oluşan sayısal çözüm ağlarına ait bilgiler Çizelge 1'de verilmiştir. A ğ eleman boyutları her defasında yarı yarıya küçültülerek sayısal analizler gerçekleştirilmiştir. En küçük (A ̆ 4) ve en büyük (Ağ 1) ağ elemanlarından oluşan hesaplama ağları arasında yaklaşık olarak 1.320 .000 eleman fark1 bulunmaktadır. A $\breve{g} 3$ ve A $\breve{g} 4$, hesaplama ağlar1 arasında yaklaşı olarak 1.000 .000 adet eleman fark1 bulunduğu Çizelgeden görülmektedir. Eleman boyutunun küçülmesiyle birlikte, sayısal modellemenin hesap süresinde de artış olduğu ve maksimum en boy oranın da arttığ1 Çizelgeden anlaşılmaktadır. En küçük elemanlardan oluşan hesaplama ağı ile en büyük elemanlardan oluşan hesaplama ağı kullanılarak yapılan sayısal analizlerin hesaplama süreleri arasında yaklaşık 11 kat fark olduğu çizelgeden görülmektedir. Sayısal analizlerde, debi sürekliliğinin yaklaşık olarak 30 s'lik çözümlerde sağlandığı belirlenmiştir.

Farklı eleman boyutlarında oluşturulan hesaplama ağı tasarımlarının görüntüleri Şekil 3 'te verilmiştir. 
Eleman boyutunun küçülmesiyle birlikte, çözüm bölgesinde bulunan eleman sayısının artması sonucunda, hesaplama ağı tamamen siyah bir görüntüye bürünmekte ve ağ elemanlarının ayırt edilmesi mümkün olmamaktadır.

\subsubsection{Duvar Yakını Modellemesi}

Sayısal modellemede, duvar yakını modellemesinde farklı duvar fonksiyonları kullanılmaktadır. Sayısal modellemede kullanılan ANSYS-Fluent paket programı, RNG türbülans modelinde duvar yakını modellemesi için, Standart (St.), Scalable (Sc.), Non-Equilibrium (N.E.), Enhanced (E.) duvar fonksiyonları gibi alternatif seçenekleri sunmaktadır [14]. Bu çalışmada, 4 farklı duvar yakını modellemesi kullanılmış ve duvar yakını modellemesinin sayısal model sonuçları üzerine etkileri de araștırılmıștır. Standart duvar fonksiyonu, taban üzerindeki ilk ağ elemanı viskoz alt tabaka içinde olmadığı ve ilk ağ elemanı log-tabaka bölgesinde yer aldığı durumlar için Launder ve Spalding [15] tarafından yapılan çalışmaya dayandırılarak genellikle endüstriyel akımların sayısal modellemesinde oldukça sık kullanılmaktadir. $\mathrm{Bu}$ duvar fonksiyonu, kat1 yüzeylerle sınırlandırılmış akımların birçoğunda oldukça başarılı sonuçlar vermektedir [14]. Non-Equilibrium duvar fonksiyonu, Standart duvar fonksiyonunun başarısız olduğu büyük basınç gradyanına sahip ve dengeli akım durumu bulunmayan problemlerde, Launder ve Spalding [15] tarafindan önerilen ortalama hız için logduvar yasasına, basınç gradyanlarının da etkisini dikkate alan bir modeldir.

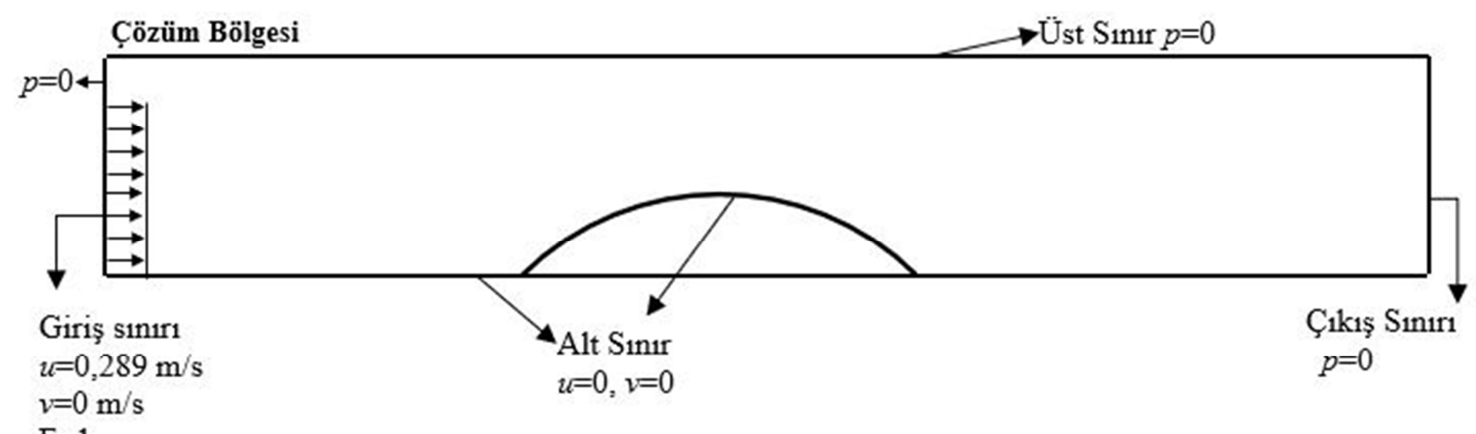

Şekil 2. Sayısal çözüm bölgesi, başlangıç ve sınır şartları

Çizelge 1. Sayısal modellemede kullanılan farklı ağ eleman boyutlarına ait bilgiler

\begin{tabular}{|c|c|c|c|c|c|}
\hline Durum & Eleman boyutu (m) & $\begin{array}{c}\text { Eleman } \\
\text { Sayısı }\end{array}$ & $\begin{array}{c}\text { Düğüm } \\
\text { sayısı }\end{array}$ & $\begin{array}{c}\text { Mak. en boy } \\
\text { oranı }\end{array}$ & $\begin{array}{c}\text { Çözüm } \\
\text { süresi }\end{array}$ \\
\hline $\mathrm{Ağ} 1$ & 0,01 & 3.376 & 10.631 & 4,70 & 11 saat \\
\hline $\mathrm{Ağ} 2$ & 0,005 & 13.294 & 40.881 & 5,40 & 24 saat \\
\hline $\mathrm{Ağ} 3$ & 0,001 & 331.418 & 999.233 & 6,04 & 60 saat \\
\hline $\mathrm{Ağ} 4$ & 0,0005 & 1.324 .748 & 3.984 .203 & 6,12 & 120 saat \\
\hline
\end{tabular}

a) Ăg 1 


\section{b) A $\mathbf{g} 2$}

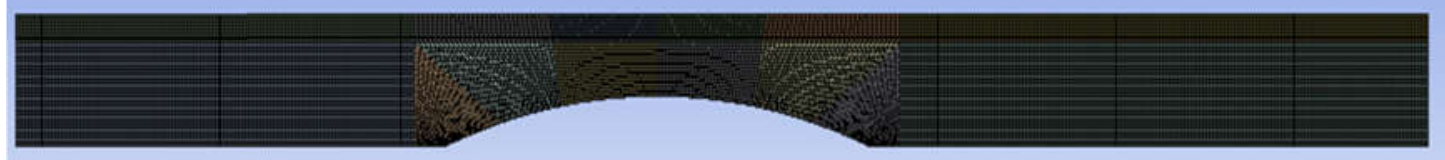

c) $\mathbf{A g} 3$

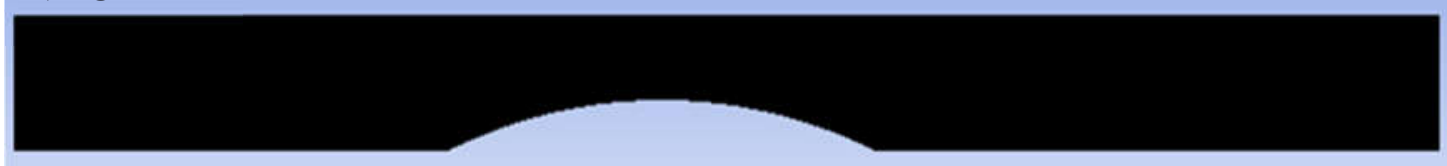

d) $\mathrm{Ag} 4$

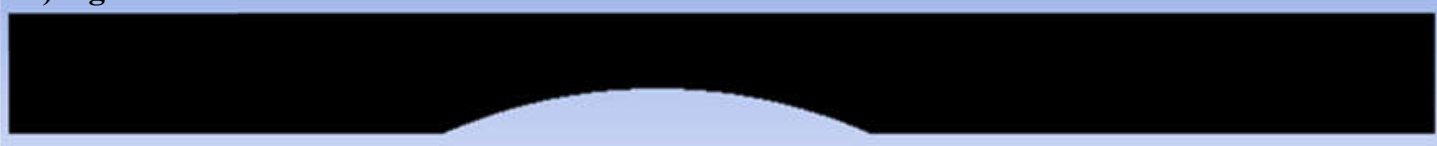

Şekil 3. Farklı eleman boyutlarına sahip hesaplama ağları

Ortalama hızın ve türbülansın, yüksek basıncın etkisinde olduğu karmaşık akım problemlerinin sayısal çözümünde duvar yakınının modellemesinde kullanılması önerilmektedir. Duvara yakın ăg elemanındaki türbülans kinetik enerjisinin miktarını hesaplamak için iki katmanlı temel yaklaşımı benimsemiştir $[14,16]$. Nonequilibrium ve standart duvar fonksiyonlarının kullanılması, duvara yakın ağ düğümünün tamamen log-law bölgesi içinde bulunduğu kabulünü taşır. Ancak bu durumun, akışla ilişkili değişen geometrik ve hız büyüklükleri nedeniyle genel uygulamalarda gerçekleşmesi zor olabilmektedir. Scalable duvar fonksiyonu, katı sınıra yakın olan ağa yakın noktayı, duvara yakın olup olmasına bakılmaksızın etkin bir şekilde log yasasına uygun sinırlara kaydırarak sinır tabakasının laminar ve geçiş bölgelerinin hatalı modellenmesini önler. Diğer bir ifadeyle, scalable duvar fonksiyonu, standart duvar fonksiyonu yaklaşımının yanında log yasasıyla birlikte kullanılmasını zorunlu kılmaktadır [14]. Enhanced duvar fonksiyonu ise iki katmanlı bir modeldir. Duvara (kanal tabanına veya yan yüzeylere) yakın hesaplama ağının yüksekliği, viskoz alt tabakanın kalınlığından daha az ise bu yöntem kullanılması önerilmektedir [14,17].

\section{BULGULAR VE TARTIŞMA}

\subsection{Deneysel ve Sayısal Su Yüzü Profilleri}

Eğrisel geniş başlıklı savakla etkileşimde bulunan açık kanal akımının sayısal modellemesinde RNG türbülans modeli kullanılmıştır. Farklı geometrik özelliklere sahip hesaplama ağı tasarımları kullanılarak elde edilen sayısal su yüzü profilleri, deneysel su yüzü profilleri ile karşılaştırılmıştır. Farklı hesaplama ağı tasarımları kullanılarak elde edilen sayısal su yüzü profillerinin deneysel profillerle karşılaştırılmasında niceliksel ölçüt olarak Eşitlik 5 ve 6'da sırasıyla verilen Ortalama Karesel Hata $(\mathrm{OKH})$ ve Ortalama Mutlak Göreceli Hata (OMGH) değerleri kullanılmıştır.

$$
\begin{aligned}
& \mathrm{OKH}=\frac{1}{N} \sum_{n=1}^{N}\left(h_{d}-h_{h}\right)^{2} \\
& \mathrm{OMGH}=\frac{1}{N} \sum_{n=1}^{N}\left|\frac{h_{d}-h_{h}}{h_{d}}\right| x 100
\end{aligned}
$$

Burada, su yüzü profillerinin karşılaştırılmasında $h_{d}$ ve $h_{h}$ sirasiyla deneysel ve hesaplanan su derinliklerini, hız profillerinin karşılaştırılmasında ise sirasıyla deneysel ve sayısal hız değerini, $N$ 
işlem yapılan akım veya hız profilinde ele alınan nokta sayısını göstermektedir.

Düzenli üçgen, düzensiz üçgen ve dikdörtgen geometriye sahip elemanlar kullanılarak elde edilen sayısal su yüzü profillerinin deneysel su yüzü profili ile karşılaştırılması Şekil 4'te verilmiştir. Şekilde verilen su yüzü profilleri incelendiğinde, farklı geometriye sahip ağ elemanlarından oluşan hesaplama ağları kullanılarak elde edilen sayısal su yüzü profillerinin, deneysel su yüzü profilleri ile oldukça uyumlu olduğu ve sayısal su yüzü profilleri arasında büyük farklılıkların bulunmadığı görülmektedir. Düzenli üçgen elemanlardan oluşan hesaplama ağında dikdörtgen ağ elemanlarından oluşan hesaplama ağına kıyasla yaklaşık 2 kat daha fazla eleman bulunmakta ve çözüm süresi de 2 kat artmaktadır. Buradan, farklı geometriye sahip elemanlardan oluşan hesap ağlarının sayısal sonuçlar üzerinde çok da etkili olmadığı belirlenmiştir.

Farklı eleman boyutları kullanılarak elde edilen sayısal su yüzü profillerinin, deneysel su yüzü profiliyle karşılaştırılması sonucunda Eşitlik 5 ve 6 kullanılarak elde edilen $\mathrm{OKH}$ ve OMGH değerleri Çizelge 2'de verilmiştir. Çizelgede verilen değerler incelendiğinde, en küçük $\mathrm{OKH}$ ve $\mathrm{OMGH}$ değerlerinin, A $\breve{g} 4$ durumda elde edildiği görülmektedir. Eleman boyutunun büyümesiyle birlikte $\mathrm{OKH}$ ve $\mathrm{OMGH}$ değerlerinde arttı̆̆ belirlenmiştir. Ağ 3 kullanılarak elde edilen OMGH değeri ile Ağ 2 kullanılarak elde edilen OMGH değerleri arasındaki fark yaklaşık olarak \%9,5 iken, Ağ 4 kullanıldığı durumda bu değer yaklaşık \%0,94 olmaktadır. Bu değerin bu kadar düşük olması Ăg 3 ve 4 kullanılarak elde edilen sayısal su yüzü profillerinin deneysel sonuçlara oldukça yakın olduğunu göstermesinin yanında yaklaşık 1.000 .000 adet fazla ağ elemanının bulunduğu çözüme de gerek duyulmayacağı sonucunu ortaya koymaktadır.

Şekil 5'te, farklı ağ elemanları için elde edilen sayısal su yüzü profillerinin deneysel su yüzü profiliyle grafiksel karşılaştırılması verilmiştir. Şekiller incelendiğinde, eleman boyutu $0,01 \mathrm{~m}$ için hesaplanan profilin, deneysel su yüzü profilinden daha aşağıda olduğu ve diğer eleman boyutları için hesap edilen profillere göre deneysel ölçümlerle daha uyumsuz olduğu görülmektedir. Eleman boyutunun küçülmesiyle birlikte sayısal su yüzü profillerinin deneysel su yüzü profiline yakınsadığ belirlenmiş̧tir.

Çizelge 2. Farklı eleman boyutları kullanılarak elde edilen su yüzü profilleri için hesaplanan OKH $\left(\mathrm{cm}^{2} / \mathrm{s}^{2}\right)$ ve OMGH $(\%)$ değerleri

\begin{tabular}{|c|c|c|c|c|c|c|c|}
\hline \multicolumn{2}{|c|}{ Ăg 1} & \multicolumn{2}{|c|}{ Ăg 2} & \multicolumn{2}{|c|}{ Ăg 3} & \multicolumn{2}{|c|}{ Ăg 4} \\
\hline OKH & OMGH & OKH & OMGH & OKH & OMGH & OKH & OMGH \\
\hline 1,2 & 17,687 & 0,53 & 14,681 & 0,09 & 5,090 & 0,06 & 4,151 \\
\hline
\end{tabular}
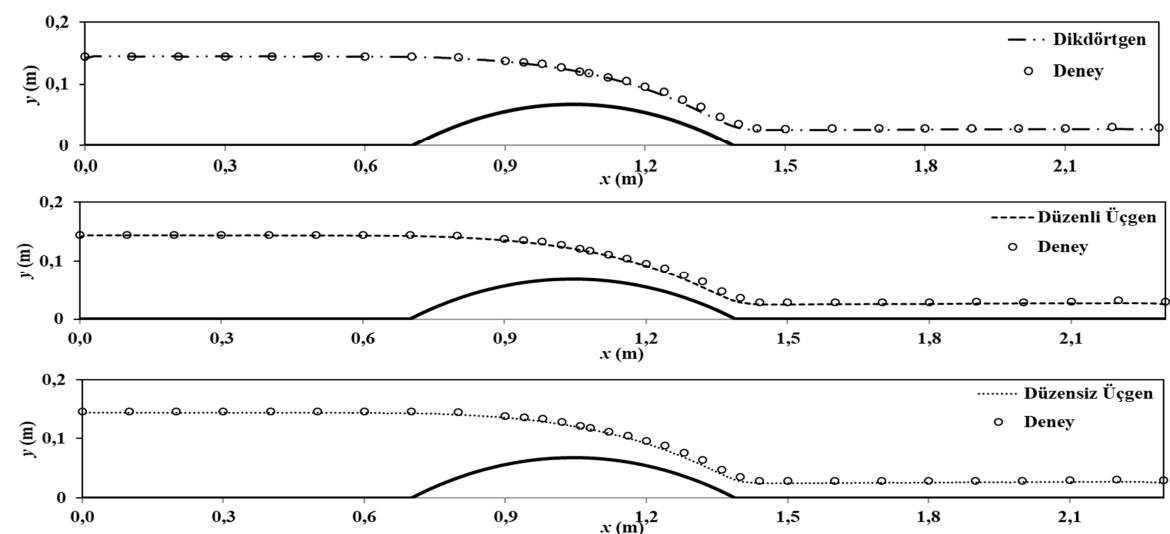

Şekil 4. Farklı geometrili ağ elemanı kullanılarak elde edilen su yüzü profilleri 
Duvar bölgesi için farklı fonksiyonlar kullanılarak elde edilen sayısal su yüzü profillerinin deneysel ölçümler ile karşılaştırılması sonucunda elde edilen $\mathrm{OKH}$ ve $\mathrm{OMGH}$ değerleri Çizelge 3 'te verilmiştir. Çizelgeden, $\mathrm{OKH}$ ve $\mathrm{OMGH}$ değerlerinin birbirine çok yakın olduğu, yani aralarında anlamlı bir farklılığın bulunmadığı söylenebilir. Bunun, sayısal modellemede eleman boyutlarının oldukça küçük olmasından kaynaklandığı düşünülmektedir. En küçük OMGH ve $\mathrm{OKH}$ değerleri $\mathrm{E}$. duvar fonksiyonu ile elde edilmiştir. Farklı duvar fonksiyonları kullanılarak elde edilen sayısal su yüzü profillerinin deneysel su yüzü profiliyle grafiksel karşılaştırılması Şekil 6'da verilmiştir. Şekiller incelendiğinde, farklı duvar yakını modellemesinde kullanılan fonksiyonların su yüzü profillerini belirlemede farklılık göstermediği ve deneysel su yüzü profiline oldukça yakın olduğu söylenebilir. $\mathrm{Bu}$ sonuç, Çizelge 3'teki değerler ile de paralellik göstermektedir.

Çizelge 3. Farklı duvar fonksiyonları kullanılarak elde edilen su yüzü profilleri için hesaplanan OKH $\left(\mathrm{cm}^{2} / \mathrm{s}^{2}\right)$ ve OMGH $(\%)$ değerleri

\begin{tabular}{|c|c|c|c|c|c|c|c|}
\hline \multicolumn{2}{|c|}{ St. } & \multicolumn{2}{c|}{ Sc. } & \multicolumn{2}{c|}{ N.E. } & \multicolumn{2}{c|}{ E. } \\
\hline OKH & OMGH & OKH & OMGH & OKH & OMGH & OKH & OMGH \\
\hline 0,065 & 4,207 & 0,068 & 4,407 & 0,069 & 4,462 & $\mathbf{0 , 0 6 3}$ & $\mathbf{4 , 1 5 1}$ \\
\hline
\end{tabular}
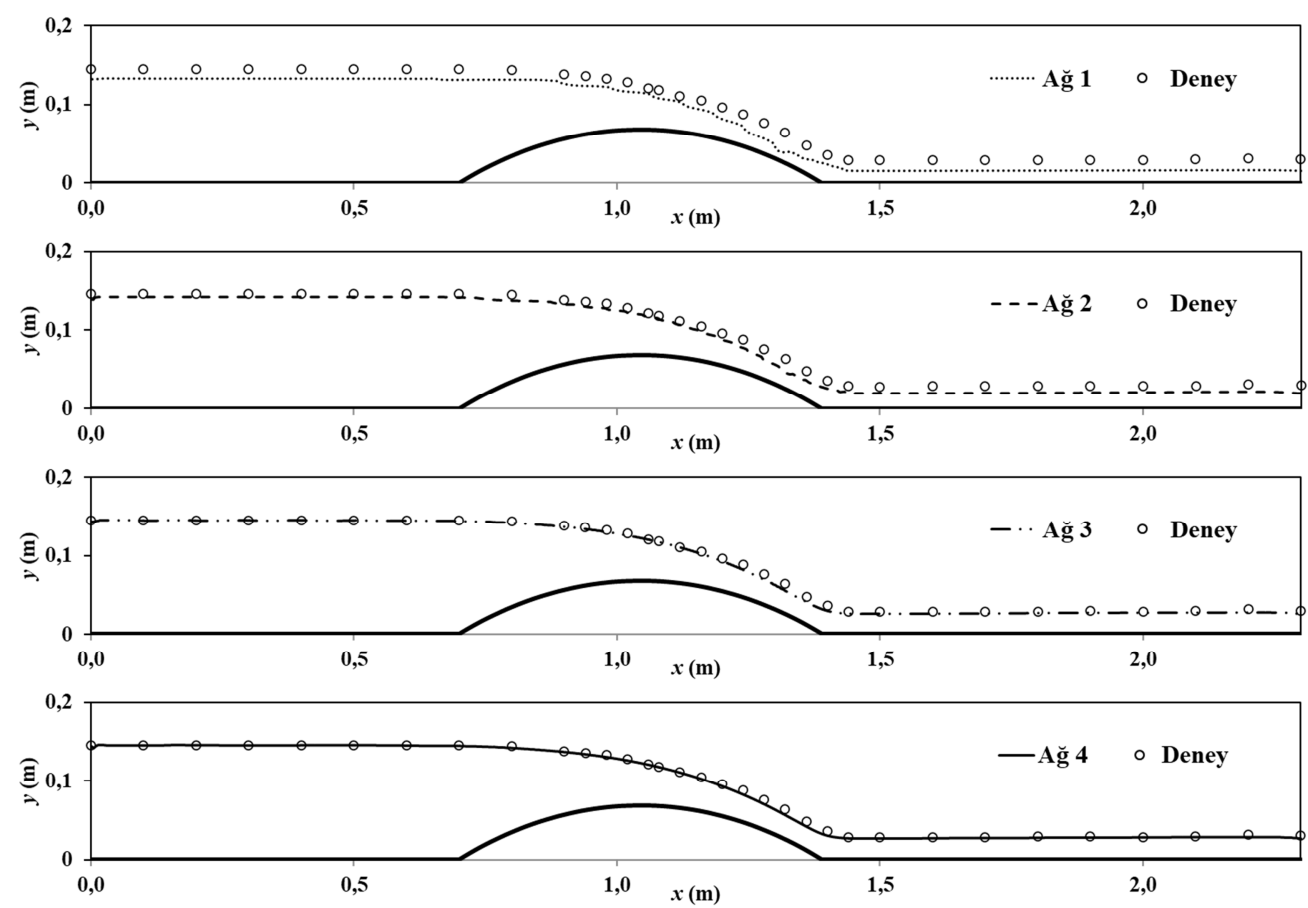

Şekil 5. Farklı ă̆ eleman boyutu kullanılarak elde edilen su yüzü profilleri

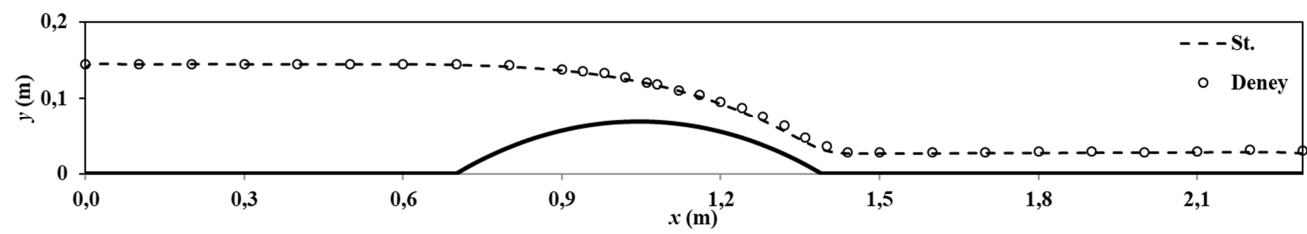



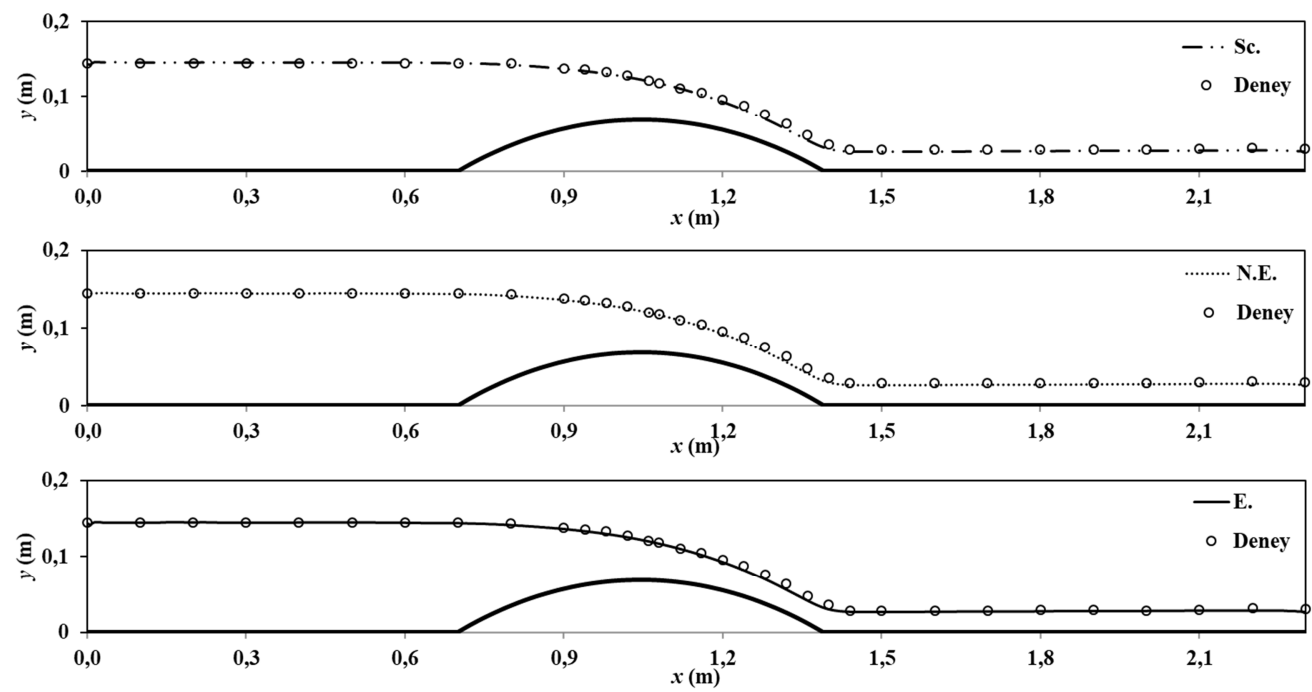

Şekil 6. Farklı duvar fonksiyonları kullanılarak elde edilen sayısal su yüzü profilleri

\subsection{Deneysel ve Sayısal Hız Profilleri}

Çizelge 4'te, farklı eleman boyutlarına sahip hesaplama ağları kullanılarak kanal boyunca farklı kesitlerde elde edilen hiz profillerini, deneysel ölçümlerle niceliksel olarak karşılaştırmak için, Eşitlik 5 ve 6 kullanılarak elde edilen $\mathrm{OKH}$ ve $\mathrm{OMGH}$ değerleri sunulmuştur. Çizelge 4 incelendiğinde, A $\breve{g} 4$ kullanılarak elde edilen $\mathrm{OKH}$ ve $\mathrm{OMGH}$ değerlerinin, diğer eleman boyutlarına ait $\mathrm{OKH}$ ve $\mathrm{OMGH}$ değerlerine kıyasla küçük olduğu görülmektedir. A $\breve{g} 1$ ve 2'nin kullanıldığı sayısal çözümlerde, $\mathrm{OKH}$ ve $\mathrm{OMGH}$ değerlerinin, Ağ 3 için elde edilen değerlerden oldukça büyük olduğu çizelgeden görülmektedir. Buna ilave olarak, A $\breve{g} 3$ ve 4 kullanılarak elde edilen OKH ve OMGH değerleri arasında oldukça küçük farkların olduğu söylenebilir. Diğer bir ifadeyle, A $\breve{g} 3$ veya Ağ 4'un kullanılması sayısal modelleme sonuçları üzerinde önemli bir fark oluşturmamaktadır. $\mathrm{Bu}$ sonuç, farklı ağ eleman boyutu kullanılarak elde edilen su yüzü profillerinde elde edilen $\mathrm{OKH}$ ve $\mathrm{OMGH}$ değerleriyle benzerlik göstermektedir. Sonuç olarak çizelgedeki değerlerden eleman boyutunun $0,001 \mathrm{~m}$ olarak alınması, ağ eleman boyutunun $0,0005 \mathrm{~m}$ olduğu duruma kiyasla, çözüm süresini kısaltması ve daha az bilgisayar donanımı gerektirmesi açısından tercih edilmesi önerilmektedir.
Şekil 7'de, farklı ağ eleman boyutları kullanılarak elde edilen sayısal hiz profillerinin deneysel profilleriyle grafiksel karşılaştırılması verilmiştir. Eğrisel geniş başlıklı savağın memba bölgesinde, $(x=0-70 \mathrm{~cm})$ kanal tabanına yakın bölgede eleman boyutunun artmasiyla deneysel ve sayisal hiz profilleri arasında farkın arttığı görülmektedir. Genel olarak bu bölgedeki hiz profilleri, eleman boyutundan bağımsız olarak, deneysel hız profilleriyle, savak mansap bölgesine kıyasla daha uyumsuzdur. Farklı eleman boyutları için sayısal hız profillerinin kanal tabanından uzaklaştıkça aynı olması, eleman boyutunun kanal tabanına yakın bölgede hiz profilleri üzerinde etkili olduğunu göstermektedir. Şekiller incelendiğinde, savak üzerinde ve savak mansap bölgesinde, deneysel ve sayısal hiz profilleri arasındaki uyum, memba bölgesine kıyasla oldukça fazladır. Mansap bölgesindeki hiz profillerinden, eleman boyutundaki küçülmenin sayısal sonuçlar üzerinde etkili olduğu ve deneysel ölçümlere daha fazla yakınsadığı açıkça görülmektedir. Ayrıca, Ağ 1 kullanılması durumda profiller arasında en fazla uyumsuzluğun olduğu da söylenebilir. A $\breve{g} 3$ ve Ağ 4 kullanilarak elde edilen profillerde bariz farklılıkların bulunmadığı Çizelge 5'teki değerlerden ve şekillerden açıkça görülmektedir. 
Çizelge 4. Farklı eleman boyutları kullanılarak elde edilen hız profilleri için hesaplanan $\mathrm{OKH}\left(\mathrm{cm}^{2} / \mathrm{s}^{2}\right)$ ve OMGH (\%) değerleri

\begin{tabular}{|c|c|c|c|c|c|c|c|c|}
\hline Eleman boyutu (m) & \multicolumn{2}{|c|}{ A $\breve{\mathbf{g}} 1$} & \multicolumn{2}{|c|}{ 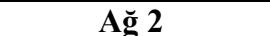 } & \multicolumn{2}{|c|}{$\mathbf{A \breve { g } 3}$} & \multicolumn{2}{|c|}{$\mathbf{A \breve { g } 4}$} \\
\hline$x(m)$ / Kriter & OKH & OMGH & OKH & OMGH & OKH & OMGH & OKH & OMGH \\
\hline $\mathbf{0 , 3 0}$ & 14,70 & 11,33 & 12,26 & 10,43 & 13,50 & 11,18 & 17,81 & 12,23 \\
\hline 0,45 & 16,32 & 11,53 & 13,62 & 10,61 & 14,29 & 10,92 & 15,18 & 11,22 \\
\hline $\mathbf{0 , 6 0}$ & 18,93 & 11,94 & 15,90 & 10,76 & 16,16 & 10,87 & 16,35 & 10,97 \\
\hline 0,65 & 7,46 & 7,87 & 10,10 & 10,75 & 15,32 & 15,68 & 15,81 & 15,91 \\
\hline 0,70 & 8,42 & 7,13 & 7,27 & 6,31 & 7,48 & 6,34 & 8,90 & 6,86 \\
\hline $\mathbf{0 , 8 0}$ & 48,66 & 10,78 & 21,62 & 7,63 & 5,30 & 5,26 & 4,53 & 5,14 \\
\hline $\mathbf{0 , 9 0}$ & 86,46 & 18,43 & 57,52 & 16,61 & 44,18 & 15,10 & 40,55 & 14,51 \\
\hline 0,95 & 120,28 & 19,38 & 76,16 & 16,68 & 57,55 & 15,02 & 53,59 & 14,47 \\
\hline 1,00 & 133,71 & 15,76 & 45,04 & 11,59 & 45,42 & 11,65 & 48,34 & 11,92 \\
\hline 1,05 & 249,43 & 11,79 & 88,13 & 7,43 & 9,66 & 4,30 & 9,39 & 4,21 \\
\hline 1,06 & 253,50 & 11,49 & 80,71 & 7,02 & 7,54 & 3,71 & 11,58 & 4,29 \\
\hline 1,10 & 382,61 & 11,36 & 117,54 & 5,06 & 0,88 & 0,79 & 5,94 & 1,32 \\
\hline 1,15 & 643,83 & 15,15 & 204,89 & 7,13 & 2,56 & 1,25 & 4,42 & 1,64 \\
\hline 1,20 & 1271,77 & 20,98 & 497,68 & 11,01 & 40,73 & 4,10 & 15,97 & 3,42 \\
\hline 1,30 & 4061,35 & 46,01 & 1124,87 & 17,30 & 45,65 & 3,42 & 6,40 & 1,84 \\
\hline 1,40 & 356,46 & 10,32 & 87,44 & 5,28 & 7,60 & 1,90 & 17,18 & 2,71 \\
\hline 1,45 & 3173,08 & 32,47 & 967,22 & 14,34 & 47,73 & 3,60 & 16,37 & 2,69 \\
\hline 1,50 & 2962,04 & 32,47 & 853,74 & 13,30 & 25,59 & 3,00 & 18,44 & 2,88 \\
\hline 1,70 & 2528,45 & 31,59 & 724,92 & 13,02 & 33,04 & 2,71 & 7,88 & 1,76 \\
\hline 1,90 & 2639,95 & 32,33 & 838,92 & 13,70 & 44,73 & 3,37 & 10,27 & 1,87 \\
\hline 2,10 & 2273,43 & 31,03 & 758,39 & 12,94 & 61,80 & 3,10 & 10,57 & 1,46 \\
\hline 2,20 & 1829,77 & 29,51 & 519,77 & 12,05 & 5,69 & 1,58 & 10,74 & 1,98 \\
\hline Ortalama & 1049,12 & 19,57 & 323,81 & 10,95 & 25,11 & 6,31 & 16,65 & 6,15 \\
\hline
\end{tabular}

Farklı duvar fonksiyonları için hesaplanan hızlar ile sayısal hızların karşılaştırılmasından elde edilen $\mathrm{OKH}$ ve OMGH değerleri Çizelge 5'te sunulmuştur. En küçük OKH ve OMGH değerleri, su yüzü profillerine benzer olarak, E. duvar fonksiyonu kullanılarak elde edilmiştir. Duvar fonksiyonlarının başarısı sıralamasının E., N.E., St. ve Sc. şeklinde oluştuğu belirlenmiştir. Duvar fonksiyonlarının hız alanını belirlemede oldukça benzer sonuçlar verdiği OKH ve OMGH değerlerinden anlaşılmaktadır. Seçilen duvar fonksiyonunun sayısal sonuçlar üzerindeki etkisinin daha anlaşılır ve çözümler arasındaki farkın daha net olabilmesi için daha kaba ağ elemanlarından oluşan hesaplama ağın oluşturulması ve sonuçlarının karşılaştırılması gerekmektedir.

Farklı duvar fonksiyonu kullanılarak elde edilen sayısal hiz profillerinin deneysel hiz profilleriyle grafiksel olarak karşılaştırılması Şekil 8'de verilmiştir. Şekilde, farklı akım özelliklerine sahip savak memba, üstü ve mansap bölgelerinde temsili seçilen kesitlerdeki profilleri sunulmuştur. Savak mansap bölgesi $x=2,20 \mathrm{~m}$ kesitinde, farklı duvar fonksiyonları kullanılarak elde edilen hiz profilleri arasında fark bulunmadiğı ve sayısal profillerin deneysel hız profili ile de oldukça uyumlu olduğu görülmektedir. Savak memba bölgesi $x=0,30$ ve $0,70 \mathrm{~m}$ kesitlerinde ise katı sınıra yakın bölgede duvar fonksiyonları arasında farklılı söz konusudur. Savak üstünde, $x=0,8,1,06$ ve 1,20 m kesitlerinde, kat1 sınıra yakın bölgenin modellemesinde tercih edilen yaklaşımın hız profili üzerindeki etkisinin azaldığı ifade edilebilir. Genel olarak, duvar fonksiyonun viskoz alt tabaka ve sınır tabakası kalınlığının fazla olduğu memba bölgesindeki hız profilleri üzerinde etkili olduğu görülmüştür. 
Çizelge 5. Farklı duvar fonksiyonları kullanılarak elde edilen hız profilleri için hesaplanan OKH $\left(\mathrm{cm}^{2} / \mathrm{s}^{2}\right)$ ve OMGH (\%) değerleri

\begin{tabular}{|c|c|c|c|c|c|c|c|c|}
\hline Duvar Fonk. & \multicolumn{2}{|c|}{ St. } & \multicolumn{2}{c|}{ Sc. } & \multicolumn{2}{c|}{ N.E. } & \multicolumn{2}{c|}{ E. } \\
\hline $\boldsymbol{x}$ (m)/Kriter & $\mathbf{O K H}$ & $\mathbf{O M G H}$ & $\mathbf{O K H}$ & $\mathbf{O M G H}$ & $\mathbf{O K H}$ & $\mathbf{O M G H}$ & OKH & OMGH \\
\hline $\mathbf{0 , 3 0}$ & 17,81 & 12,23 & 20,85 & 12,99 & 19,45 & 12,26 & 17,54 & 11,54 \\
\hline $\mathbf{0 , 4 5}$ & 15,18 & 11,22 & 15,68 & 11,41 & 13,35 & 10,30 & 11,65 & 9,29 \\
\hline $\mathbf{0 , 6 0}$ & 15,10 & 10,97 & 15,41 & 11,37 & 14,09 & 9,56 & 12,92 & 8,09 \\
\hline $\mathbf{0 , 6 5}$ & 15,81 & 15,91 & 16,26 & 16,52 & 10,76 & 12,91 & 8,76 & 11,19 \\
\hline $\mathbf{0 , 7 0}$ & 8,90 & 6,86 & 9,28 & 7,05 & 9,02 & 7,81 & 8,55 & 7,91 \\
\hline $\mathbf{0 , 8 0}$ & 4,53 & 5,14 & 4,68 & 5,17 & 4,53 & 5,04 & 4,54 & 5,06 \\
\hline $\mathbf{0 , 9 0}$ & 40,55 & 14,51 & 41,40 & 14,69 & 43,00 & 14,96 & 40,40 & 14,34 \\
\hline $\mathbf{0 , 9 5}$ & 53,59 & 14,47 & 54,43 & 14,59 & 55,01 & 14,64 & 51,95 & 14,20 \\
\hline $\mathbf{1 , 0 0}$ & 48,34 & 11,92 & 51,02 & 12,11 & 47,52 & 11,79 & 46,58 & 11,66 \\
\hline $\mathbf{1 , 0 5}$ & 9,39 & 4,21 & 10,41 & 4,37 & 9,34 & 4,24 & 11,39 & 4,63 \\
\hline $\mathbf{1 , 0 6}$ & 11,58 & 4,29 & 13,89 & 4,49 & 11,38 & 4,22 & 14,21 & 4,69 \\
\hline $\mathbf{1 , 1 0}$ & 5,94 & 1,32 & 8,29 & 1,56 & 6,62 & 1,42 & 8,59 & 1,76 \\
\hline $\mathbf{1 , 1 5}$ & 4,42 & 1,64 & 5,11 & 1,65 & 4,52 & 1,56 & 5,63 & 1,65 \\
\hline $\mathbf{1 , 2 0}$ & 15,97 & 3,42 & 15,70 & 3,31 & 14,70 & 3,14 & 17,09 & 3,38 \\
\hline $\mathbf{1 , 3 0}$ & 6,40 & 1,84 & 7,13 & 1,89 & 6,44 & 1,79 & 5,41 & 1,64 \\
\hline $\mathbf{1 , 4 0}$ & 18,09 & 2,76 & 10,53 & 2,02 & 9,16 & 2,10 & 11,41 & 2,27 \\
\hline $\mathbf{1 , 4 5}$ & 16,31 & 2,69 & 22,53 & 3,15 & 19,35 & 2,95 & 16,50 & 2,80 \\
\hline $\mathbf{1 , 5 0}$ & 18,44 & 2,88 & 30,43 & 3,46 & 27,83 & 3,30 & 24,65 & 3,27 \\
\hline $\mathbf{1 , 7 0}$ & 7,84 & 1,75 & 14,74 & 2,40 & 14,49 & 2,40 & 11,22 & 2,10 \\
\hline $\mathbf{1 , 9 0}$ & 10,11 & 1,85 & 9,00 & 1,85 & 9,30 & 1,86 & 11,18 & 2,11 \\
\hline $\mathbf{2 , 1 0}$ & 10,14 & 1,45 & 7,58 & 1,38 & 7,72 & 1,42 & 6,16 & 1,31 \\
\hline $\mathbf{2 , 2 0}$ & 10,74 & 1,98 & 16,48 & 2,59 & 16,72 & 2,62 & 17,94 & 2,52 \\
\hline Ortalama & 16,60 & 6,15 & 18,22 & 6,37 & 17,01 & 6,01 & $\mathbf{1 6 , 5 6}$ & $\mathbf{5 , 7 9}$ \\
\hline
\end{tabular}
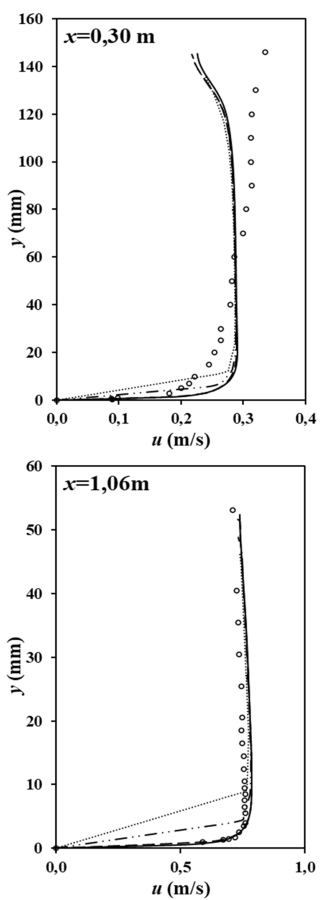
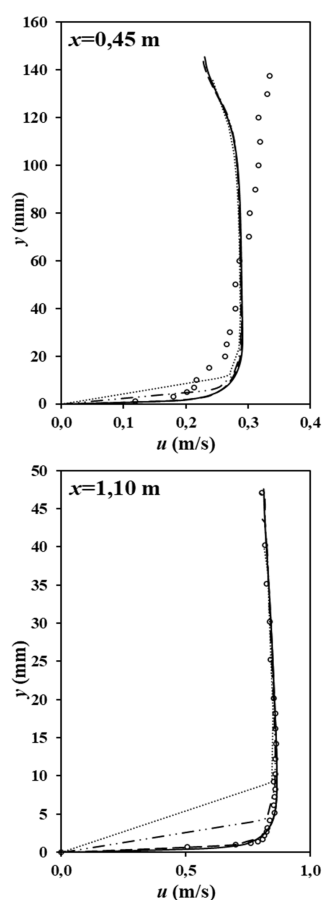
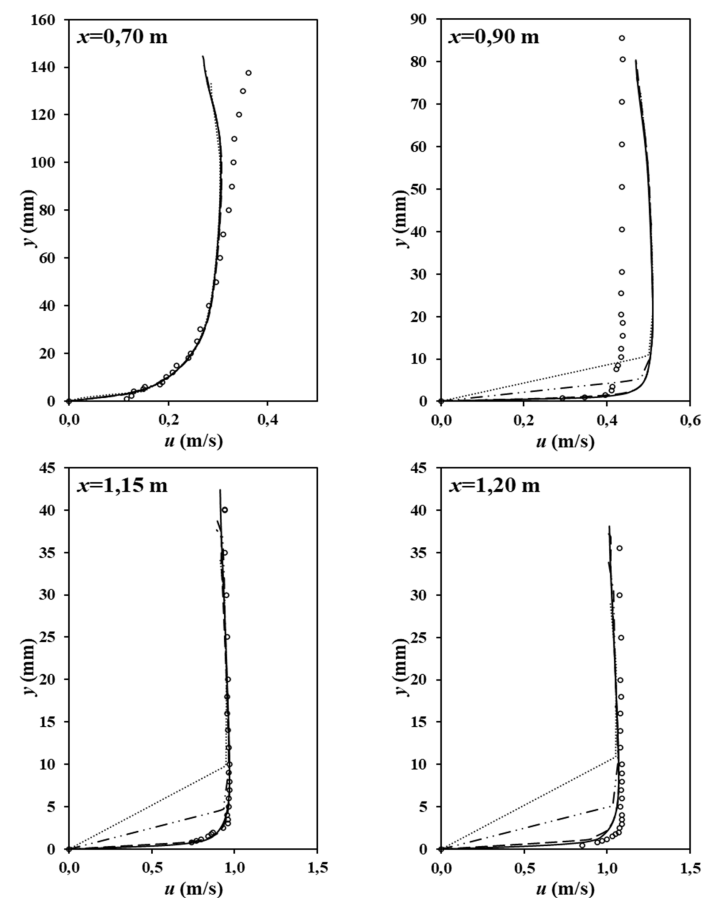

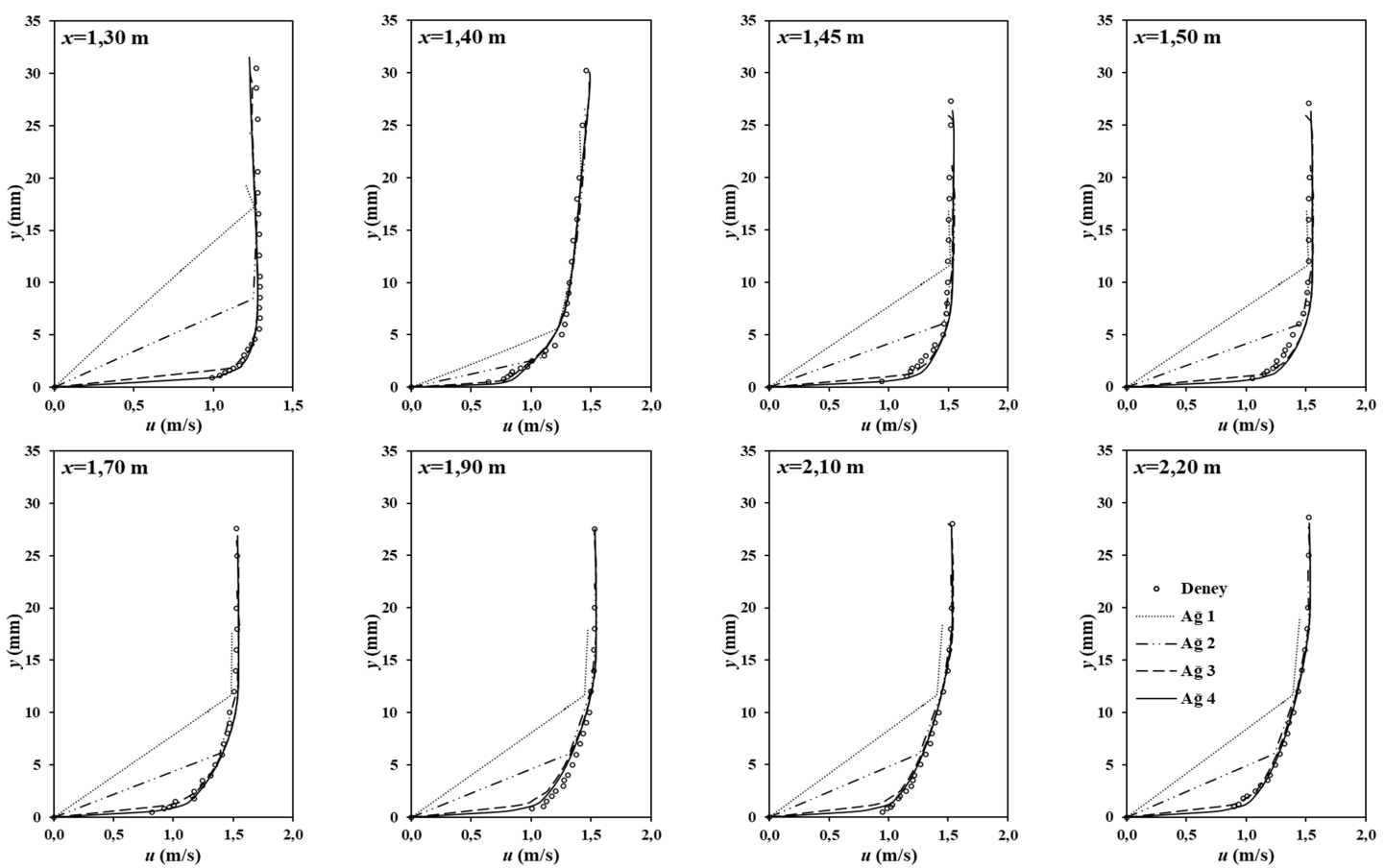

Şekil 7. Farklı ağ eleman boyutları kullanılarak elde edilen sayısal hız profilleri
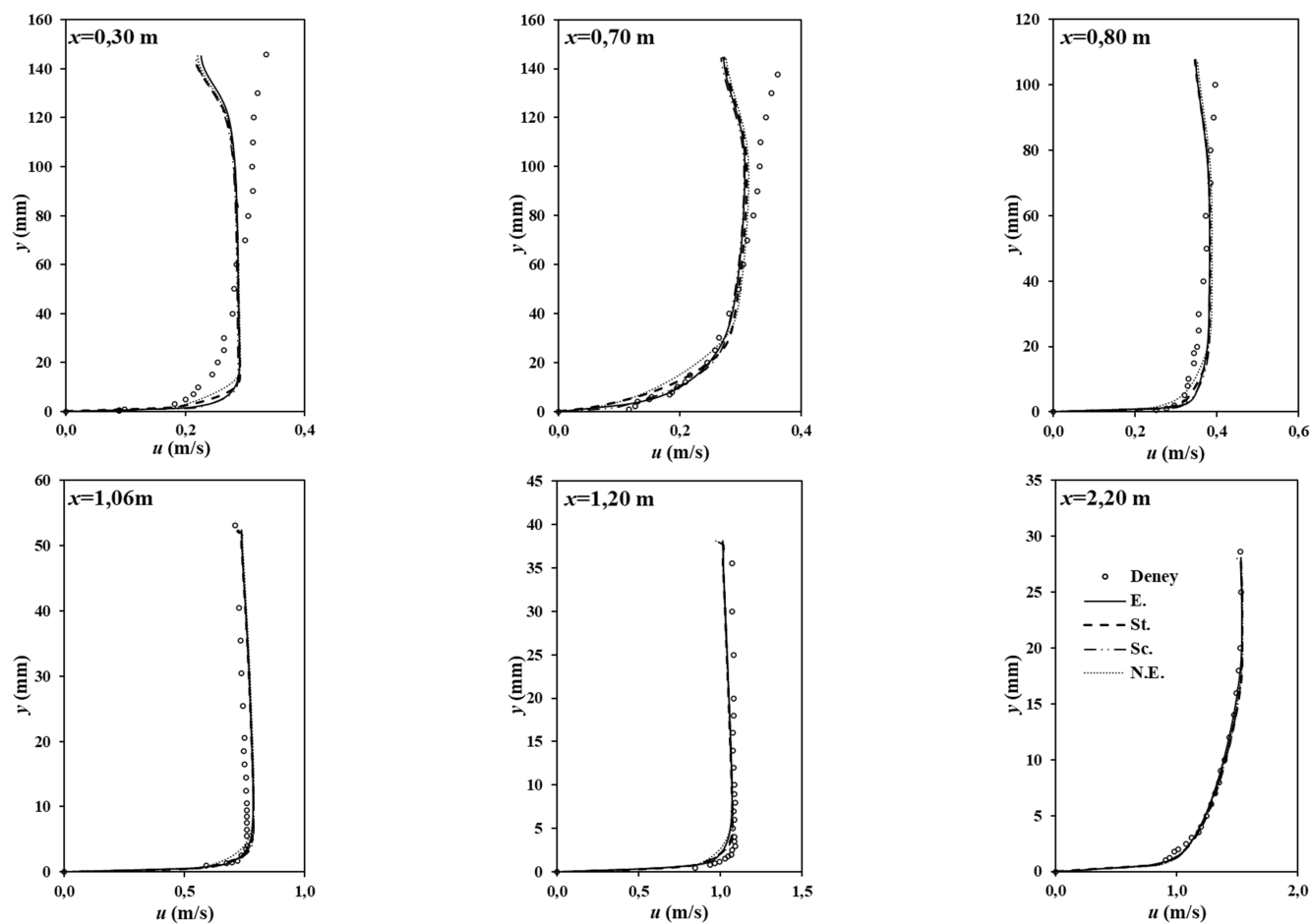

Şekil 8. Farklı duvar fonksiyonları kullanılarak elde edilen sayısal hız profilleri 


\section{SONUÇLAR}

Eğrisel geniş başlıklı savak akımını idare eden temel denklemlerin sayısal çözümleri, sonlu hacimler yöntemine dayalı ANSYS-Fluent paket programı yardımıyla yapılmıştır. Sayısal modellemede, serbest su yüzü profilleri akışkan hacimleri yöntemiyle hesaplanmıştır. Dört farklı ă eleman sayısı ve dört farklı duvar fonksiyonu kullanılarak hesaplanan akım hızları ve su yüzü profilleri deneysel ölçümlerle karşılaştırılmıştır. Hesaplama ağında kullanılan eleman boyutlarının küçültülmesi ile sayısal su yüzü ve hız profillerinin deneysel ölçümlere yakınsadığı ancak belli bir noktadan sonra küçültmenin sonuçlar üzerinde etkili olmadığ 1 görülmüştür. Enhanced duvar fonksiyonu kullanılarak elde edilen sayısal hız ve akım profillerinin bu çalışmada kullanılan diğer duvar modellerine kıyasla daha başarılı olduğu sonucuna ulaşılmıştır. Su yüzü profillerinin sayısal hesaplamalarında, katı sınıra yakın bölgenin modellemesinde kullanılan duvar fonksiyonlarının etkisinin olmadı̆̆ hesaplama ağını oluşturan elemanların farklı geometrik şekillerde olmasının sayısal bulgular üzerindeki etkisi net olarak görülememiştir.

\section{KAYNAKLAR}

1. Telkıran, M.N., Aköz, M.S., Şimşek, O., Soydan, N.G., 2019. Dolusavak Üzerinden Geçen Akımın Sayısal Analizi: Mersin Dereyurt Göleti Dolusavak Örneği, Çukurova Üniversitesi Mühendislik Fakültesi Dergisi, 34(1), 155-167.

2. Şimşek, O., Soydan, N.G., Gümüş, V., Aköz, M.S., Kırkgöz, M.S., 2015. Ani Bir Düşüdeki B-tipi Hidrolik Siçramanın Sayısal Modellenmesi, IMO Teknik Dergi, 26(4), 7215-7240.

3. Gümüş, V., Şimşek, O., Soydan, N.G., Aköz, M.S., Kirkgöz, M.S., 2015. Numerical Modeling of Submerged Hydraulic Jump from a Sluice Gate, Journal of Irrigation and Drainage Engineering, 142(1), 04015037.

4. Soydan, N.G., Şimşek, O., Aköz, M.S., 2018. Köprü Ayağı Etrafındaki Türbülanslı Akımın
Sayısal ve Deneysel Analizi, Politeknik Dergisi, 21(1), 137-147.

5. Aköz, M.S., Soydan, N.G., Şimşek, O., 2016. Kritik Üstü Açık Kanal Akımının Detached Eddy ve Large Eddy Simülasyon ile Sayısal Modellenmesi, Gazi Üniversitesi Fen Bilimleri Dergisi Part: C, Tasarım ve Teknoloji, 4(4), 213-224.

6. Lee, C.H., Xu, C., Huang, Z., 2019. A Threephase Flow Simulation of Local Scour Caused By a Submerged Wall Jet with a Water-air Interface, Advances in Water Resources, 129, 373-384.

7. Soydan, N.G., Aköz, M.S., Şimşek, O., Gümüş, V., 2012. Trapez Kesitli Geniş Başlıklı Savak Akımının k- $\varepsilon$ Tabanlı Türbülans Modelleri ile Sayısal Modellenmesi, Çukurova Üniversitesi Mühendislik-Mimarlık Fakültesi Dergisi, 27(2), 47-58.

8. Kırkgoz, M.S., Aköz, M.S., Öner, A.A., 2009. Numerical Modeling of Flow Over a Chute Spillway, Journal of Hydraulic Research, 47(6), 790-797.

9. Çelik, I.B., Ghia, U., Roache, P.J., Freitas, C.J., 2008. Procedure for Estimation and Reporting of Uncertainty Due to Discretization in CFD Applications, Journal of Fluids EngineeringTransactions of the ASME, 130 (7).

10. Şimşek, O., Parmaksız, M., Gümüş, V., 2019. Radyal Kapak ile Etkileşimde Bulunan Açık Kanal Akımının Sayısal Modellenmesi, Niğde Ömer Halisdemir Üniversitesi Mühendislik Bilimleri Dergisi, 8(2), 965-978.

11. Şimşek, O., Aköz, M.S., Soydan, N.G., 2016. Numerical Validation of Open Channel Flow Over a Curvilinear Broad-crested weir, Progress in Computational Fluid Dynamics, an International Journal, 16(6), 364-378.

12. Yakhot, V., Orszag, S.A., 1986. Renormalization-group Analysis of Turbulence, Physical Review Letters, 57(14), 1722-1724.

13. Hirt, C.W., Nichols, B.D., 1981. Volume of Fluid (VOF) Method for the Dynamics of Free Boundaries, Journal of Computational Physics, 39(1), 201-225.

14. ANSYS, FLUENT Theory Guide. USA: ANSYS Inc., 2012. 
15. Launder, B.E., Spalding, D.B., 1974. The Numerical Computation of Turbulent Flows, Computer Methods in Applied Mechanics and Engineering, 3, 269-289.

16. Kim, S., 1995. A Near-wall Treatment Using Wall Functions Sensitized to Pressure Gradient, Separated and Complex Flows, In ASME FED, 217.

17. Huang, P., Bradshaw, P., Coakley, T., 1993. Skin Friction and Velocity Profile Family for Compressible Turbulent Boundary Layers, AIAA Journal, 31(9), 1600-1604. 
